\title{
NOTES ON FOOD OF Capricornis milneedwardsii IN THE CAT BA ARCHIPELAGO, HAI PHONG, VIETNAM
}

\author{
Phan Duy Thuc*, Dao Ngoc Hieu, Hoang Van Thap, Vu Hong Van, Nguyen Xuan Khu \\ Cat Ba National Park, Hai Phong, ${ }^{(*)}$ pduythuc@gmail.com
}

\begin{abstract}
The Southwest China serow, Capricornis milneedwardsii, is widespread through Myanmar, Cambodia, northern Thailand, Laos, central and southwest China, and Vietnam. However, this species is listed as Near Threatened in IUCN Red List and its ecology, especially the diet of this species is poorly understood. The data of food plants of the Serow in Cat Ba Archipelago was taken by interviewing the Cat Ba National Park's rangers and members of forest protection groups on the feeding sites of the species, and then conducting field surveys. The results of interviews were carefully crosschecked in the field to determine the food plants of the Serow in the Cat Ba Archipelago. The species' food plants were collected in the browsing zone up to $1.5 \mathrm{~m}$ above ground and uneaten parts of less than $5 \mathrm{~mm}$ in diameter. The study found that at least 33 different plant species of 22 families was determined as food plants of the serow in the archipelago. These plants were mostly found in secondary evergreen moist forests on limestone, accounting for $71 \%$, and most of the species' food plants are shrubs, accounting for $73 \%$. The serows also feed mainly on the leaves and twigs of shrubs and low growing trees and thus the Southwest China serow is categorized as a typical browser. Most of the plant species consumed by the serows have utility as medicinal herbs and edible sources for humans and thus they are being massively exploited by local people. This may have an impact on the population viability of the Southwest China serow in the Cat Ba Archipelago.
\end{abstract}

Keywords: Capricornis milneedwardsii, food plants, isolated population, karst landscape, serow threatened species, Cat Ba.

\section{INTRODUCTION}

The Southwest China serow, Capricornis milneedwardsii (David, 1869), is a forest dwelling mammal, and most frequently associated with rugged steep hills and rocky places, especially in limestone forests up to 4,500 m a.s.l., with scattered shrubs and high slope [12]. However, they also inhabit lowland montane forests with gentler terrain and flat areas [3].

The Southwest China serow is likely to tolerate moderately degraded forests and small isolated karsts limestone hills and cliffs in both natural karts scrubland and disturbed habitats [3]. They appear to often be found in areas inaccessible to human encroachment [3], which is most likely a behavioral response to avoid human disturbance. This species prefers secondary forests to primary forests; however, it is unlikely to occur in heavily disturbed habitats as agricultural land [3]. It is mostly nocturnal, solitary, and territorial [13]. Several individuals are sometimes in the same area; however, they feed some distance [13].

Although the species is listed as Near Threatened in the IUCN Red List [7] and Endangered in the Vietnamese Red Book [2], it is found in Myanmar, Cambodia, northern Thailand, Laos, central and southwest China, and Vietnam [4]. Moreover, the data on ecology of this species are either unknown or extremely limited throughout most of its range, with the exception of three informative studies so far. Lovari and Locati (1994) [11] determined the serows' physical uses of territorial areas by their feces in Khao Sam Roi Yot National Park, Thailand. Wu et al. (2000) [18] studied on serow habitat selection of the serow in the spring and winter in Sichuan province, China. And $\mathrm{Wu}$ and Zhang (2004) [17] conducted a research on habitat selection and its seasonal change in Tibet, China.

So far, there have been very few studies on the feeding ecology of this species, and thus the diet of this species is poorly understood. It is only known that the species feeds on a wide 
range of leaves and shoots, and visits to saltlicks as basic information for the diet of this species [3]. Therefore, this study was designed to initially determine the food plants for the species in the Cat Ba Archipelago with a hope of an improved understanding of the diet of the Southwest China serow in the Cat $\mathrm{Ba}$ Archipelago for further interest, research and conservation actions to conserve this species.

\section{MATERIALS AND METHODS}

\section{Study site}

Cat Ba Archipelago Biosphere Reserve (latitude $20^{\circ} 44^{\prime}-20^{\circ} 52^{\prime} \mathrm{N}$ and longtitude $106^{\circ} 59^{\prime}-107^{\circ} 06^{\prime}$ E) is a limestone archipelago with an area of over $240 \mathrm{~km}^{2}$, consisting of one main island and 366 small islands (figure 1). $\mathrm{Cat} \mathrm{Ba}$ island is one of the largest islands of the archipelago, which is about $45 \mathrm{~km}$ east of Hai Phong city, $25 \mathrm{~km}$ south of Ha Long city and
$150 \mathrm{~km}$ south-east of Ha Noi.

\section{Topography and hydrology}

Cat $\mathrm{Ba}$ Archipelago is a limestone karst landscape rising abruptly from the sea. The topography is rugged and marked by steep outcrops and areas of bare rock, where much of the elevation is between $50 \mathrm{~m}$ and $200 \mathrm{~m}$ a.s. 1 . Ten percent of the archipelago is below $50 \mathrm{~m}$, but several peaks are over $200 \mathrm{~m}$, with the highest peak being is Cao Vong, which is $332 \mathrm{~m}$.

The archipelago is a typical in welldeveloped karst landscape, and thus most of the streams are seasonal, flowing only after tropical rainstorm. However, some of the streams in the higher valleys are perennial or semi-perennial. In the rainy season, most of the rainwater flows and leaks into underground caves. This water plays an important role in providing water for plants and animals on the island.

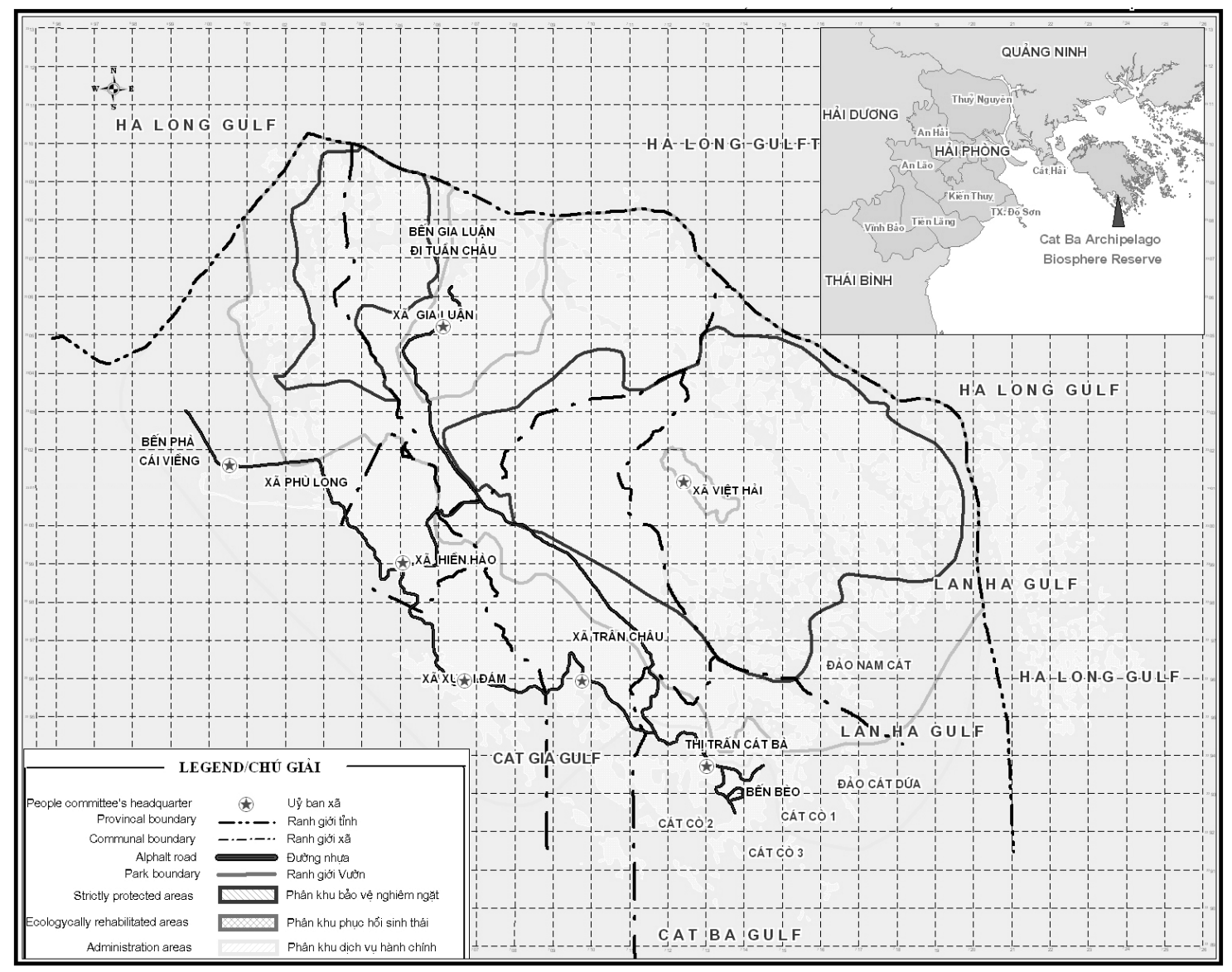

Figure 1. Cat Ba archipelago biosphere reserve map 


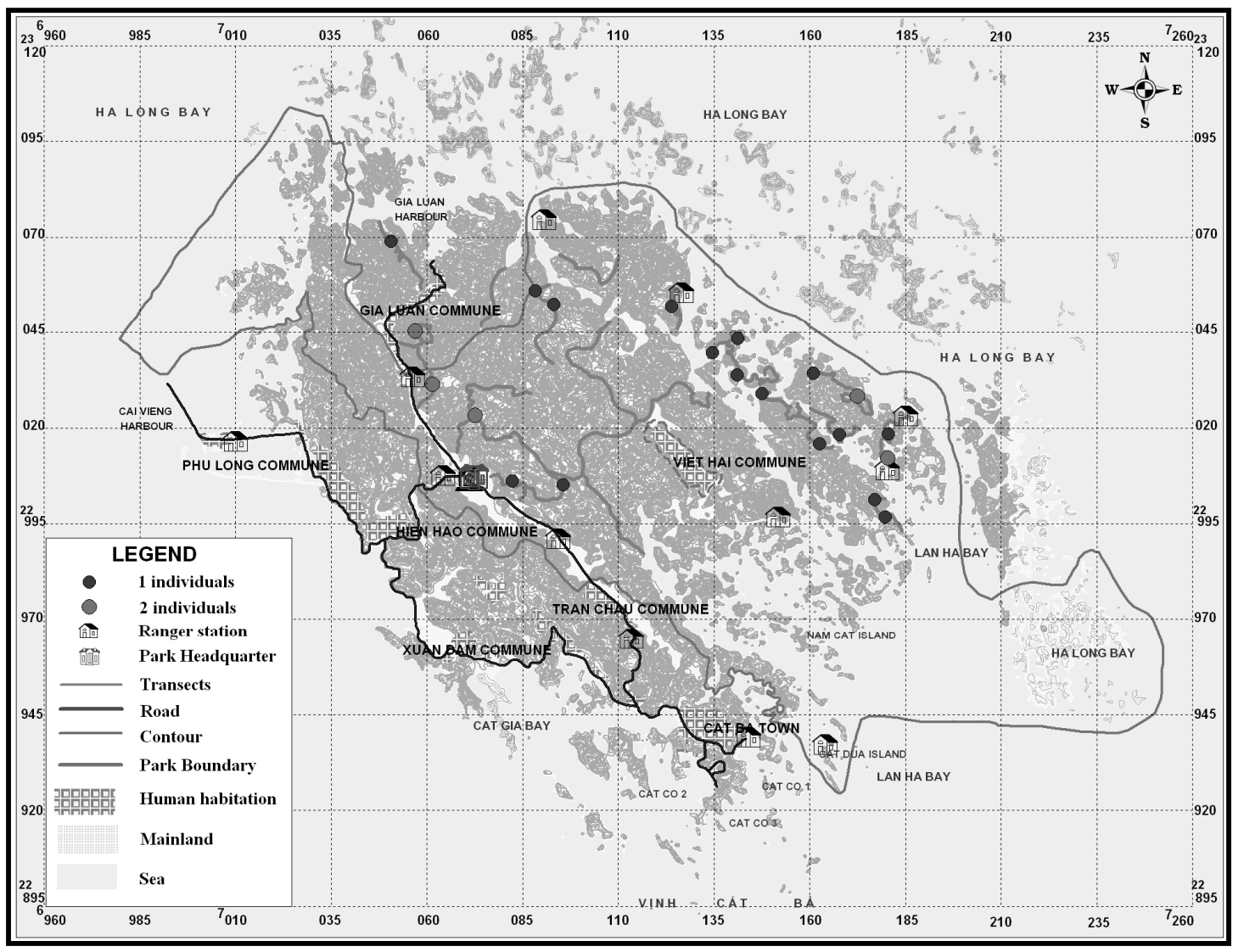

Figure 1. Distribution map of the serow and survey transects in the Cat $\mathrm{Ba}$ archipelago

\section{Flora}

The main natural vegetation type on the archipelago is limestone forest. However, the forest has been subjected to high levels of disturbance, and large areas have been replaced by limestone shrub or bare rock.

A description of the three main vegetation types, where the signs of serows were recorded, as following:

\section{Secondary evergreen moist forests on limestone}

This vegetation type covers 4,900.2 ha, accounting for $27 \%$ of the total area of forest vegetation. This is the second largest forest type on the archipelago and is distributed throughout elevations of 100-200 m. The composition of forest plant species is not only of tropical plant species but also includes indicator species for this type of forest, including; Excentrodendron tonkinense, Garcinia fagraeoides, Streblus spp.,
Chukrasia tabularis, Pometia pinnata, Caryodaphne tonkinensis, Fernandoa spp. and Saraca dives.

Grass, shrubs, regenerating plants on limestone

This vegetation type covers an area of $8,016.7$ ha, accounting for $45 \%$ of the total native vegetation. This is the largest vegetation type in the archipelago and mainly distributed across limestone areas, on which the growth and development of plants is very slow and difficult. The composition of plant species consists mainly of small trees, which are resistant to strong wind, drought and high temperature, such as Streblus iliciflia, Streblus laciflorus, Streblus maciophylus, Diospyros sp., Vatica odorata, Alangium chinesis, Euphoria frugifera, Xerospermum honhianum, Syzygium sp., Archiodendron clypearia. Shrubs average 5-6m high. Although, the coverage of this vegetation type is not high, about $30 \%$ of the island's rare 
and endemic animals, such as the Cat Ba langur, rhesus monkey, serow and python mainly inhabit in this area.

\section{Non-forest or bare rock}

There are 2,502 ha of bare rock without trees or very few trees, accounting for $14 \%$ of the land covered by native vegetation. Most species of plants cannot survive in this type, and only a few shrubs and trees can grow in this area.

To date, 1,561 vascular plant species have been recorded in the archipelago, including 60 species listed in the Vietnamese Red Book and 29 species listed in the IUCN Red List. Thus, the Cat $\mathrm{Ba}$ Archipelago has 72 plant species, listed in both Vietnamese Red Book and IUCN.

\section{Fauna}

In a recent study, 53 mammal species (18 families), 160 bird species (46 families), 45 reptile species (15 families) and 21 amphibian species (5 families) were recorded in the Cat $\mathrm{Ba}$ Archipelago. Of 279 terrestrial species, 22 species are listed in the Vietnamese Red Book and 7 species are listed in the international red list.

\section{Methods}

\section{Interviews}

Questionnaires were prepared to interview members of Forest Protection Groups (FPGs) and rangers of Cat Ba National Park on the food plants consumed by serow in Cat $\mathrm{Ba}$ Archipelago. These people regularly patrol the forests to monitor biodiversity and control illegal activities from local people. Therefore, they have opportunities to observe the feeding signs of serows in the forests. By interviewing rangers and FPGs' members, locations of feeding signs and habitat preference were collected, contributing to clarify the areas of potential distribution of serows and in designing the survey routes. Additionally, traditional knowledge of the local people on the ecology of serow, especially on food plants was also collected.

\section{Field surveys}

The locations of feeding sites and other sites of the serows provided by these people were crosschecked in the field. The feeding signs and food plants consumed by the serow was recorded directly along serow tracks (figure 2). These were identified by the released feces, footprints, and rubbings of horn and body on trees and around sleeping sites. Once the areas of these signs were found, we checked carefully to find the uneaten parts in the trees. The remaining uneaten parts of the plants were collected in a horizontal zone up to $1.5 \mathrm{~m}$ above ground [9], along with twigs of $<5 \mathrm{~mm}$ in diameter [16]. Additionally, food plants for serow were also identified by using the indigenous knowledge of local people.

\section{Data analysis}

All plant parts including leaves and fruits were collected and used to classify specimens to species if possible, following [5]. After identification the plants, species were compared to samples stored at Cat Ba National Park for verification. If the specimens could not be classified, they were sent to plant specialists in the Forest Inventory and Planning Institute, Hanoi for identification and classification.

\section{RESULTS AND DISCUSSION}

At least 33 different plant species of 22 families was determined as food plants of the serow in this study (table 1). Twenty-six of the total 33 plant species were identified to species, six plants were identified to genera, and one plant was identified to family (table 1).

The families, those have the highest number of plant species in the diet of the serow were Moraceae, Begoniaceae and Rubiaceae, where three species of each family were consumed by the serow. Each family of Euphorbiaceae, Rhamnaceae, Poaceae, Myrsinaceae, and Urticaceae had 2 plant species that were consumed by the serow. The remaining families contributed one species for food plants of the serows (table 1).

Our observation showed that the serow has a preference for consuming leaves and twigs. Serows fed on leaves from 27 plant species and twigs with buds from 6 species. The twigs came from three species of Begoniaceae and three species of Rosaceae, Myrsinaceae and Aspleniaceae (table 2). 
Table 1. List of plant families with number of species consumed by the serow

\begin{tabular}{|l|c|c|l|c|c|}
\hline \multicolumn{1}{|c|}{ Family } & Genus & Species & \multicolumn{1}{c|}{ Family } & Genus & Species \\
\hline Acanthaceae & 1 & 1 & Moreceae & 3 & 3 \\
\hline Anacardiaceae & 1 & 1 & Myrsinaceae & 2 & 2 \\
\hline Asteraceae & 1 & 1 & Myrtaceae & 1 & 1 \\
\hline Asclepiadaceae & 1 & 1 & Poaceae & 2 & 2 \\
\hline Aspleniaceae & 1 & 1 & Rhamnaceae & 2 & 2 \\
\hline Begoniaceae & 1 & 3 & Rosaceae & 1 & 1 \\
\hline Caseasalpiniaceae & 1 & 1 & Rubiacea & 3 & 3 \\
\hline Clusiaceae & 1 & 1 & Rutaceae & 1 & 1 \\
\hline Euphorbiaceae & 2 & 2 & Urticaceae & 2 & 2 \\
\hline Fabaceae & 1 & 1 & Verbenaceae & 1 & 1 \\
\hline Liliaceae & 1 & 1 & Vitaceae & 1 & 1 \\
\hline
\end{tabular}

Table 2. Plant parts consumed by the serows

\begin{tabular}{|l|c|c|}
\hline Plant parts & Number of species & Percentage of species \\
\hline Leaf only & 28 & $85 \%$ \\
\hline Twig with buds & 5 & $15 \%$ \\
\hline
\end{tabular}

Table 3. Life form of plants consumed by the serow

\begin{tabular}{|l|c|c|}
\hline Life form & Number of species & Percentage of total species \\
\hline Trees & 5 & $15.15 \%$ \\
\hline Shrubs & 24 & $72.72 \%$ \\
\hline Liana & 4 & $12.12 \%$ \\
\hline
\end{tabular}

The lower storey of forest, from ground to below $1.5 \mathrm{~m}$ was the browsing zone of the serow and thus most of food plants were shrubs, accounting for $73 \%$ of the plant species recorded as consumed by the serows (table 3 ).

Most of the plant species consumed by the serow have utility as medicinal herbs and edible sources for human (table 4), and they are listed the medicinal plants and herbs of Vietnam [12].

During this study we recorded serow food plants along serow tracks up to 1.5 above the ground. The remnant parts of browsed plants were all smaller than $5 \mathrm{~mm}$ in diameter, that allowed to distinguish serow browsing from that caused by the other two large mammals left in the archipelago; the Golden headed langur and the Rhesus monkey. The two species of monkey use their hands to pick leaves or other plant parts to feed, while serows use their mouths to consume food plants and thus the remnant plant parts that were not eaten were different in the size of diameter. In addition, the foraging sites of the two species of monkey usually have food plant material dropped on the ground.

Table 4. The utility of food plants of the species

\begin{tabular}{|l|c|c|}
\hline \multicolumn{1}{|c|}{ Utility } & Number of species & Percentage of total species \\
\hline Medicine only & 16 & $48.48 \%$ \\
\hline Food only & 9 & $27.27 \%$ \\
\hline Medicine and food & 7 & $21.21 \%$ \\
\hline Unidentified to species & 1 & $3 \%$ \\
\hline
\end{tabular}


Table 5. Vegetation types and locations where found the food plants of serow

\begin{tabular}{|c|c|c|c|c|c|c|}
\hline \multirow{2}{*}{ No. } & \multirow{2}{*}{ Scientific name } & \multirow{2}{*}{ Area } & \multirow{2}{*}{$\begin{array}{l}\text { Vegetation } \\
\text { type }\end{array}$} & \multicolumn{2}{|c|}{ Coordinate } & \multirow{2}{*}{ Elevation } \\
\hline & & & & $\mathrm{X}$ & $\mathrm{Y}$ & \\
\hline 1 & Streblus macrophyllus & Van Ta & 2 & 716925 & 2303058 & 112 \\
\hline 2 & Streblus macrophyllus & Gio Cung & 6 & 716217 & 2301637 & 25 \\
\hline 3 & Streblus macrophyllus & Tra Bau & 2 & 712440 & 2305295 & 140 \\
\hline 4 & Streblus macrophyllus & Tra Bau & 2 & 714093 & 2303640 & 59 \\
\hline 5 & Urtica thunbergiana & Gia Luan & 2 & 705145 & 2306947 & 89 \\
\hline 6 & Urtica thunbergiana & Gio Cung & 6 & 716200 & 2301650 & 95 \\
\hline 7 & Urtica thunbergiana & Tra Bau & 2 & 714053 & 2304244 & 71 \\
\hline 8 & Acanthus ebracteatus & Van Ta & 2 & 716925 & 2303058 & 112 \\
\hline 9 & Acanthus ebracteatus & Tra Bau & 2 & 714132 & 2303456 & 95 \\
\hline 10 & Zizyphus rugosa & Gia Luan & 2 & 705145 & 2306947 & 89 \\
\hline 11 & Zizyphus rugosa & Van Ta & 2 & 716158 & 2303410 & 115 \\
\hline 12 & Ficus racemosa & Tra Bau & 2 & 712431 & 2305323 & 142 \\
\hline 13 & Ficus racemosa & Tra Bau & 2 & 712450 & 2305313 & 140 \\
\hline 14 & Callicarpa arborea & Gia Luan & 2 & 705192 & 2306912 & 156 \\
\hline 15 & Canthium dicoccum & Gia Luan & 2 & 705134 & 2306949 & 82 \\
\hline 16 & Maesa montana & Gia Luan & 2 & 705134 & 2306949 & 82 \\
\hline 17 & Sageretia theezas & Gia Luan & 2 & 705122 & 2306959 & 67 \\
\hline 18 & Mycetia $\mathrm{sp}$ & Gia Luan & 2 & 705708 & 2304355 & 143 \\
\hline 19 & Garcimia pedunculata & Gia Luan & 2 & 705746 & 2304156 & 71 \\
\hline 20 & Diplazium esculentum & Gia Luan & 2 & 705918 & 2303735 & 35 \\
\hline 21 & Embelia laeta & Gia Luan & 2 & 706102 & 2303421 & 175 \\
\hline 22 & Rhus semialata & Gia Luan & 2 & 707061 & 2302950 & 45 \\
\hline 23 & Duchesnea indica & Gia Luan & 2 & 705842 & 2304201 & 70 \\
\hline 24 & Xanthium inaequilateum & Gia Luan & 6 & 705447 & 2304177 & 150 \\
\hline 25 & Mussaenda sanderiana & Gia Luan & 10 & 705939 & 2304242 & 203 \\
\hline 26 & Begonia laciniata & Van Ta & 2 & 717057 & 2302718 & 136 \\
\hline 27 & Begonia aptera & Van Ta & 2 & 717210 & 2302699 & 103 \\
\hline 28 & Vitis balanseana & Van Ta & 2 & 717130 & 2302987 & 143 \\
\hline 29 & Dendrocnide urentissima & Van Ta & 2 & 717103 & 2303021 & 144 \\
\hline 30 & Phyllanthus reticulatus & Van Ta & 2 & 717347 & 2302942 & 84 \\
\hline 31 & Dalbergia $\mathrm{sp}$. & Van Ta & 2 & 718019 & 2301911 & 20 \\
\hline 32 & Rhodomyrtus tomentosa & Gio Cung & 6 & 716662 & 2301797 & 23 \\
\hline 33 & Evodia lepta & Gio Cung & 10 & 716951 & 2301806 & 11 \\
\hline 34 & Groton tonkinensis & Gio Cung & 6 & 717758 & 2300069 & 49 \\
\hline 35 & Cudraria cochinchinensis & Tra Bau & 2 & 712440 & 2305295 & 140 \\
\hline 36 & Bauhinia khasiana & Tra Bau & 6 & 712470 & 2305242 & 112 \\
\hline 37 & Begonia boisiana & Tra Bau & 2 & 712501 & 2305041 & 112 \\
\hline 38 & Asclepiadaceae & Tra Bau & 2 & 714159 & 2304392 & 136 \\
\hline 39 & Lophatherum gracile & Tra Bau & 10 & 714023 & 2304284 & 128 \\
\hline 40 & Dracaena cambodiana & Tra Bau & 6 & 714141 & 2304374 & 124 \\
\hline 41 & Gigantochloa sp. & Tra Bau & 6 & 714146 & 2304354 & 110 \\
\hline
\end{tabular}

2. Secondary forest; 6. Shrubs and young trees; 10. Non-forests or bare rock [7]. 
The food plants found in this study may not be a reflection of the total number of food plants consumed by the serows in the Cat $\mathrm{Ba}$ Archipelago as the rugged limestone mountains made it difficult to access and record information at all feeding sites. The Japanese serow is known to feed on at least 114 plant species of 56 families, of which sixty are deciduous broadleaved trees, 5 evergreen coniferous trees, 46 forbs, 2 graminoids and one fern [14]. The Himalayan serow is known to feed on 38 species, including 11 trees species, 8 shrubs and 19 herbs [1]. Saola Pseudoryx nghetinhensis, is an ungulate species of the same family as serow (Bovidae) and feeds on 58 species of 38 families in captive condition [15].

This study found that the serow fed mostly food plants in secondary evergreen moist forests on limestone, which is the second largest of the vegetation types (accounting for $27 \%$ of all vegetation types) in the archipelago, and which accounts for $71 \%$ of the vegetation types found food plants of the serows (table 5). The next vegetation type preferred by the serow were shrubs, regenerating trees on limestone, which is the largest of vegetation types (accounting for $45 \%$ of all vegetation types) in the archipelago, which accounts for $24 \%$ of the food plants consumed by the serow (as recorded in this study). This is believed that secondary forests supported more food plants for serows than other types of vegetation. This would be a way of habitat selection as the species affect the choice of plants available to them by selecting the vegetation types which best satisfy its feeding requirements [9]. Within these vegetation types, the serow consumed $73 \%$ of shrubs for their habitat selection, means that shrubs were selected as suitable stands of plants, and finally from those shrubs, leaf and twig with buds were probably chosen to eat. Jarman (1973) [9] described this is different level of habitat selection of the serow.

Most of the food plants consumed by the serow have medicinal value and/or are sources of food for human [12]. In this respect, the diet of the serow is similar to the diet of Saola that has $54 \%$ of its food plants used as medicinal herbs by human [15].
Local people, especially the poor, also illegally collect some of these medicinal plants for home consumption and sale. For example, local residents harvested 3,357 $\mathrm{kg}$ of Dracaena cambodiana in 2010 for trading, and 514 households $(35.8 \%$ of total of households in six communes) in the archipelago were confirmed to regularly collect medicinal herbs. Thus, as well as direct mortality from hunting, the local people may have an impact on serow through food competition when they collect some food plants of the serow.

The present study found that five of thirtythree species of food plants, such as Strebls macrophyllus (4 records), Urtica thunbergiana (3 records), and Acanthus ebracteatus, Zizyphus rugosa and Ficus racemosa (2 records respectively) were probably most preferred by the species.

In this study, the food plants consumed by the serow were inferred from the remnant/partially eaten parts found along the serow feeding trails, and thus only leaf and twigs with buds were recorded. The leaf contributed a large proportion $(85 \%)$ in diet of the serow. These leaves came from 27 species of woody plants. Twigs with buds came from 6 species, in which 3 species were succulent body and 3 species were sour taste. According to the high proportion of browse in its diet that feed mainly on the leaves and twigs of shrubs and low growing trees [6], the Southwest China serow is categorized as a typical browser. This is similar to other serow species. The Japanese [14] and Himalayan [1] serows have been confirmed as typical browsers. However, the Formosan serow is an intermediate feeder between a selective browser and a roughage eater [6] with a tendency towards being a selective browser [14].

\section{CONCLUSION}

At least 33 different plant species of 22 families was determined as food plants of the Southwest China serow in the Cat $\mathrm{Ba}$ Archipelago. These plants were mostly found in secondary evergreen moist forests on limestone, accounting for $71 \%$, and most of the species' food plants are shrubs, accounting for $73 \%$. The 
species also feeds mainly on the leaves and twigs of shrubs and low growing trees and thus the Southwest China serow is categorized as a typical browser. Most of the plant species consumed by the serows have utility as medicinal herbs and edible sources for humans and thus they are being massively exploited by local people. This may have an impact on the population viability of the Southwest China serow in the Cat Ba Archipelago.

Acknowledgements: This study was funded by Scientific Funds of Hai Phong city and supported by Cat Ba National Park.

\section{REFERENCES}

1. Aryal A., 2008. Status and conservation of Himalayan serow in Annapurna Conservation Area of Nepal. BRTF Nepal; A report submitted to the Rufford Small For Nature Conservation, UK and The People's Trust For Endangered Species, UK.

2. Bộ Khoa học và Công nghệ, Viện Khoa học và Công nghệ Việt Nam, 2007. Sách đỏ Việt Nam. Phần I: Động vật. Nxb. Khoa học tự nhiên và Công nghệ.

3. Duckworth J. W., Steinmetz R., Pattanavibool A., 2008. Capricornis milneedwardsii. In: IUCN 2010. IUCN Red List of Threatened Species. Version 2010.1. Viewed 25 May 2010, www.iucnredlist.org.

4. Grubb P, 2005. Artiodactyla. In D. E. Wilson and D. M. Reeder (eds.) Mammal Species of the World. A Taxonomic and Geographic Reference (3rd edition). Johns Hopkins University Press, Baltimore, USA, pp. 637-722.

5. Phạm Hoàng Hộ, 2000. Cây cỏ Việt Nam. Tập 1, 2 và 3 . Nxb. Trẻ, tp. Hồ Chí Minh.

6. Hofmann R. R., 1989. Evolutionary steps of ecophysiological adaptation and diversification of ruminants: a comparative view of their digestive system. Oecologia., 78: 443-457.

7. Howard, J. A, and Schade, J. 1982. Towards the global remote sensing of vegetation change hierarchical classification. FAO, Rome, Italy.

8. IUCN, 2012. The IUCN Red List of Threatened Species v.2012.1. http://www.iucnredlist.org [accessed 15 July 2012].

9. Jarman P. J., 1973. The social organization of antelope in relation to their ecology. Animal Ecology Research Group, Department of Zoology, Oxford, England.

10. Jiang Z., Torii H., Takatsuki S., Ohba T., 2008. Local variation in diet composition of the Japanese serow during winter. Zoological Science., 25: 1200-1226.

11. Lovari S., Locati M., 1994. Site features of territorial dung marking in mainland serow. Mammalia., 58: 153-156.

12. Đỗ Tất Lợi, 1999. Những cây thuốc và vị thuốc Việt Nam. Nxb. Y học, Hà Nội.

13. MacKinnon J., 2008. Order Artiodactyla. In A.T. Smith \& Y. Xie (eds.) A guide to the mammals of China. Princeton, New Jersey: Princeton University Press.

14. Ochiai K., 1999. Diet of the Japanese serow (Capricornis crispus) on the Shimokita Peninsula, northern Japan, in reference to variations with a 16-year interval. Mammal Study., 24: 19-102.

15. Lê Sáu (Chủ biên), 1996. Công trình Khoa học Kỹ thuật Điều tra Quy hoạch rừng từ năm 1991-1995. Nxb. Nông nghiệp, Hà Nội.

16. Sone K., Okymura H., Abe M., Kitahara E., 1998. Biomass of food plants and density of Japanese serow, Capricornis crispus. Mem. Fac. Agr. Kagoshima University., 25: 7-16.

17. Wu P., Zhang E., 2004. Habitat selections and its seasonal change of serow (Capricornis sumatraensis) in Cibagou Nature Reserve, Tibet. Acta Theriological Sinica. 2004.01.

18. Wu H., Hu J. C., Chen W. L., Quyang W. F., Xian F. H., 2000. Habitat selection by mainland serow in spring and winter. Zoological Research., 21: 355-360. 


\title{
DẪN LIỆ VỀ THỨC ĂN CỦA LOÀI SƠN DƯƠNG (Capricornis milneedwardsii) TẠI QUẦN ĐẢO CÁT BÀ, HẢI PHÒNG, VIẸT NAM
}

\author{
Phan Duy Thức, Đào Ngọc Hiếu, Hoàng Văn Thập, Vũ Hồng Vân, Nguyễn Xuân Khu \\ Vườn Quốc gia Cát Bà, Hải Phòng
}

\section{TÓM TẮT}

Loài sơn dương (Capricornis milneedwardsii) có phạm vi phân bố từ Myanmar, Campuchia, phía Bắc Thái Lan, Lào, miền Trung và Tây Nam Trung Quốc và Việt Nam. Tuy nhiên, loài này được liệt kê vào các loài bị đe doạ trong Danh lục đỏ của thế giới, còn sinh thái học và tập tính loài, đặc biệt là các loài cây thức ăn chưa được nghiên cứu. Nghiên cứu này tập trung xác định các loài cây thức ăn của loài sơn dương trên quần đảo Cát Bà, gồm phỏng vấn kiểm lâm và người dân địa phương về các khu vực phân bố và cây thức ăn của loài, và khảo sát thực địa. Từ kết quả phỏng vấn, tiến hành khảo sát và kiểm chứng ở thực địa một cách kỹ lưỡng để xây dựng một danh lục cây thức ăn của loài Sơn dương trên quần đảo Cát Bà. Cây thức ăn của loài sơn dương được thu thập trong vùng có chiều cao từ $0 \mathrm{~m}$ tới $1,5 \mathrm{~m}$ so với mặt đất và đường kính của vết còn lại chưa ăn nhỏ hơn $5 \mathrm{~mm}$. Ít nhất có 33 loài thực vật khác nhau của 22 họ được xác định là cây thức ăn của sơn dương trên quần đảo Cát Bà. Có tới $71 \%$ các loài cây thức ăn của loài được tìm thấy trong rừng thứ sinh ầm thường xanh, và hầu hết các loài cây thức ăn là cây bụi, chiếm $73 \%$. Sơn dương ăn chủ yếu là lá và cành, vì vậy, loài này được coi là một loài điển hình ăn cành và chồi non. Hầu hết các loài cây thức ăn của sơn dương có giá trị về làm thuốc hoặc có giá trị thực phẩm cho con người. Vì vậy, người dân địa phương đang khai thác các loài cây này với một khối lượng lớn, điều này có thể ảnh hưởng đến sự sinh trưởng và phát triển của loài sơn dương trên quần đảo Cát Bà.

Tù khóa: Capricornis milneedwardsii, cây thức ăn, loài đang bị đe doạ, sinh cảnh núi đá vôi, Cát Bà.

Ngày nhận bài: 13-5-2012 